Article

\title{
Bioremediation of Waste Water to Remove Heavy Metals Using the Spent Mushroom Substrate of Agaricus bisporus
}

\author{
Marina Corral-Bobadilla $1, * \mathbb{C}$, Ana González-Marcos ${ }^{1}$, , Eliseo P. Vergara-González ${ }^{2}$ and \\ Fernando Alba-Elías 1 \\ 1 Department of Mechanical Engineering, University of La Rioja, 26004 Logroño, La Rioja, Spain; \\ ana.gonzalez@unirioja.es (A.G.-M.); fernando.alba@unirioja.es (F.A.-E.) \\ 2 Department of Mining Exploitation and Prospecting, University of Oviedo, \\ 33004 Oviedo, Principality of Asturias, Spain; vergaraeliseo@uniovi.es \\ * Correspondence: marina.corral@unirioja.es; Tel.: +34-941-299-274
}

Received: 22 January 2019; Accepted: 26 February 2019; Published: 4 March 2019 updates

\begin{abstract}
The presence of heavy metals in waste water brings serious environmental pollution that threatens human health and the ecosystem. Bioremediation of heavy metals has received considerable and growing interest over the years. Thus, this paper presents the use of the Spent Mushroom Substrate (SMS) of Agaricus bisporus cultivation as a bioremediating agent to remove heavy metals that are present in industrial waters. These metals include chromium, lead, iron, cobalt, nickel, manganese, zinc, copper and aluminium. In particular, this study analyses the performance of SMS bioreactors with different groups of heavy metals at various concentrations. Between $80 \%$ and $98 \%$ of all contaminants that were analysed can be removed with $5 \mathrm{~kg}$ of SMS at hydraulic retention times of 10 and 100 days. The best removal efficiencies and longevities were achieved when removing iron (III), nickel and cobalt from contaminated water at a $\mathrm{pH}$ of 2.5. These results suggest that SMS can successfully treat waste water that has been contaminated with heavy metals.
\end{abstract}

Keywords: bioremediation; heavy metals; Spent Mushroom Substrate; sulphate reduction

\section{Introduction}

Industrialization and technological advancement have put an increasing burden on the environment by releasing large quantities of hazardous waste, heavy metals and organic contaminants, which have inflicted serious damage on the ecosystem [1]. During the last two decades, the management of hazardous materials, such as heavy metals, has received a great deal of attention [2]. According to Wang and Chen [3], one of the greatest problems in recent times has been the treatment of wastewaters, especially those originating from metal industries. These types of effluents have big concentrations of heavy metals. Examples of the metals that exist in these effluents are $\mathrm{Zn}, \mathrm{Pb}$, $\mathrm{Cr}, \mathrm{Ni}, \mathrm{Cu}, \mathrm{Mn}, \mathrm{Co}, \mathrm{Al}$ and so forth, which come mainly from different industries (Table 1). Heavy metals pollution has caused a serious threat to the environment due to wastewater irrigation, sludge applications, solid waste disposal, automobile exhaust and industrial waste dumping [4]. Although some heavy metals act as essential micronutrients for living beings, they have the potential to produce effects that are toxic to living organisms, if used in a higher proportion than necessary [5].

Chemical precipitation, chemical oxidation or reduction, electrochemical treatment, evaporative recovery, filtration, ion exchange, adsorption by activated carbon and membrane technologies and other, conventional metal removal technologies have been used to remove heavy metal ions from industrial waste water. However, these processes may be ineffective or expensive [6]. Most of them 
require a substantial financial input. As a result, their use is restricted when cost factors override the importance of pollution control. Applying biotechnology to metal pollution control is gaining attention increasingly because it is considered to be clean and non-environmentally disruptive and an efficient strategy for remediation of a wide range of heavy metals [7]. Adsorption is extensively applied due to the flexibility of the process. Consequently, many adsorbents with high adsorption capacity have been investigated for the elimination of water contaminants [8]. Waste materials of agricultural, industrial and municipal origin have been widely used in the adsorption process as adsorbents [9]. The use of low cost adsorbents that have been developed from waste materials has several advantages, mainly of economic and environmental benefit.

Table 1. Sources of heavy metals.

\begin{tabular}{ll}
\hline \multicolumn{1}{c}{ Metal } & \multicolumn{1}{c}{ Source } \\
\hline Aluminium & Mining, processing of aluminium. \\
Cobalt & Mining, processing of cobalt-bearing ores, fertilizers. \\
Chromium & Dyeing, electroplating, paints production, steel industries, tanning, textile. \\
Copper & Copper polishing, mining, paint, plating, pesticides, printing operations. \\
Iron & Mining, iron and steel industry, fertilizers, herbicides. \\
Lead & Coal combustion, electroplating, insecticide and herbicides, manufacturing of batteries, \\
Manganese & mining, paint, pigments. \\
Nickel & Aining and mineral processing. \\
Zinc & porcelain enamelling. \\
\hline
\end{tabular}

Bioremediation is an environmentally friendly and cost-effective technique for heavy metal removal, when compared to conventional chemical and physical techniques, which are often more expensive and ineffective, especially for low metal concentrations. In addition, these conventional methods generate significant amounts of toxic sludge [10]. The biosorption of heavy metals is a biological method that has been recognized as an attractive alternative to physicochemical methods [11]. Recently, however, there has been much interest in bioremediation technologies, which use plants and microorganisms to degrade toxic contaminants in environmental soil into substances that are less toxic. The United States Environmental Protection Agency (USEPA) defines bioremediation as a treatability technology that uses biological activity to reduce the concentration and/or toxicity of a pollutant [12].

Biosorbents for the removal of metals include various bacteria, fungi, algae, industrial wastes, agricultural wastes and other polysaccharide materials. In general, most types of biomaterials have demonstrated a good biosorption capacity for many types of metal ions [13]. It is known, for example, that the bioremediation of waste water with algae offers an efficient means of sequestering heavy metals and delivering an improved quality of water for discharge to the environment [14]. Because removing heavy metals by waste microbial biomass may be economically feasible, a large number of materials was investigated recently for use in developing low-cost biosorbents from industrial and agricultural wastes. The latter include activated sludge [15], rice husks [16], egg shells [17] and chicken feathers [18]. In this sense, many studies have been recently published in pursuit of an effective and efficient agricultural waste that will adsorb heavy metals [19,20].

Accordingly, this study seeks to investigate the feasibility of using spent mushroom substrate (SMS) from Agaricus bisporus cultivation as a bioremediating agent for the removal of heavy metals from industrial waters.

SMS, which is the pasteurized organic material that is left after harvesting mushrooms is an environmental nuisance to the environment. The use of dung as a substrate, the composting operation itself and the uncontrolled sale of dung create serious environmental problems, as the air pollution and odours attract flies or other insects that transmit diseases. There is no effective treatment for SMS. Consequently, the disposal and storage of SMS residue have become a significant environmental issue and a cause of severe environmental pollution [21,22]. 
As the mushroom industry grows, the volume of SMS that it generates annually also grows. This is the situation in the Autonomous Community of La Rioja (CAR), Spain, where production of Agaricus bisporus and Pleurotus ostreatus mushrooms has increased greatly in recent years. In fact, about sixty percent of the Spanish mushroom crop is cultivated in La Rioja, where production rose from 26,512 to 66,090 tons between 1992 and 2010 [23]. Annual production today reaches no less than 72,000 tons. Considering that the production of one kilogram of mushrooms generates about five kilograms of SMS [24], the present annual production of SMS in La Rioja is estimated to be 360,000 tons. Since the production of Agaricus bisporus exceeds that of Pleurotus ostreatus by a ratio of approximately 12:1 in La Rioja, the annual production of SMS from Agaricus bisporus can be estimated to be approximately 330,000 tons.

The compost that is used to grow Agaricus bisporus, which is known also as white button mushroom, consists of straw, poultry manure, horse manure, gypsum and urea. This mixture is supplied to mushroom growers in $20 \mathrm{~kg}$ polyethylene bags. Spawn is added to the compost. Then, the bags are placed into growing rooms. After two weeks, the compost has been colonized completely by mycelium and can be covered by a casing material, usually limestone gravel (high purity calcium carbonate) and peat. The compost that is used to grow Pleurotus ostreatus, the oyster mushroom, is very similar to that used for Agaricus bisporus. However, more straw is used and no casing material is required.

The use of SMS as a bioremediating agent is supported by its properties of a nearly neutral $\mathrm{pH}$ and notable content of organic carbon and calcium [25]. The most important components of SMS for the treatment of industrial waters are limestone, gypsum, organic matter and its volume [26,27]. The re-use of SMS is not a new development. Some studies propose that SMS be used as a renewable fuel to generate power [28]. However, since SMS is a valuable source of organic matter and nutrients, it has potential uses in agriculture [29,30], horticulture [31,32], livestock feeding [33] and bioremediation of various types of pollutants. The latter include: polycyclic aromatic hydrocarbons -PAHs- [34], fungicides [35,36], pesticides [37], petroleum [38], acid mine drainage [39,40] and textile effluents [41]. Several authors have tested different methods of SMS use for the bioremediation of Lentinus edodes to remove cadmium, chromium [42,43] and lead by Tricholoma lobayense [44]. More recently, $\mathrm{Xu}$ et al. [45] reported the use of spent Agaricus bisporus to remove lead and cadmium from aqueous solutions. However, no experiments have been conducted without pre-treating (drying) the SMS and agitating the samples using incubators at different speeds of rotation. Furthermore, there has been no report of any study in which SMS from Agaricus bisporus was used to remove zinc, iron (II and III), cobalt, nickel, manganese, copper, aluminium, chromium and lead.

The bioremediation processes that could justify the removal of heavy metals when SMS is used as a bioremediating agent, are described below. The limestone solution produces the necessary alkalinity (in the form of $\mathrm{HCO}_{3}{ }^{-}$), which is equivalent to the alkalinity produced by the sulphate reduction (Equation (1)).

$$
\mathrm{CaCO}_{3}+\mathrm{CO}_{2}+\mathrm{H}_{2} \mathrm{O} \rightarrow \mathrm{Ca}^{2+}+2 \mathrm{HCO}_{3}^{-}
$$

The bicarbonate that is produced can consume free hydrogen ions, thus raising the $\mathrm{pH}$ of the acidic water (Equation (2)).

$$
\mathrm{HCO}_{3}{ }^{-}+\mathrm{H}^{+} \rightarrow \mathrm{CO}_{2}+\mathrm{H}_{2} \mathrm{O}
$$

When the SMS is exposed to acidic water, $\mathrm{Ca}^{2+}$ is filtered. Thus, high concentrations appear in the effluent in relation to the incoming water. Differences in calcium concentrations between one and the other can be used as an indicator of the alkalinity that limestone dissolution has generated. The reduction of sulphate (sulphate-reduction) that occurs in anaerobic sediments and can be described by the following reaction (Equation (3))

$$
2 \mathrm{CH}_{2} \mathrm{O}+\mathrm{SO}_{4}{ }^{2-} \rightarrow \mathrm{HS}^{-}+2 \mathrm{HCO}_{3}{ }^{-}+\mathrm{H}^{+}
$$


where $\mathrm{CH}_{2} \mathrm{O}$ represents the decomposing organic matter that is present in the SMS. If the ferrous ion (an example of a heavy metal) is present in the interstitial water, the following reaction (Equation (4)) will take place quickly.

$$
\mathrm{Fe}^{2+}+\mathrm{HS}^{-} \rightarrow \mathrm{FeS}_{(\mathrm{s})}+\mathrm{H}^{+}
$$

In this way, the reduction of sulphate $\left(\mathrm{SO}_{4}{ }^{2-}\right)$ produces $\mathrm{HS}^{-}$, which combines with $\mathrm{Fe}^{2+}$ to produce solid iron sulphide (FeS). Water-saturated SMS is capable of forming a complete anoxic zone that is sensitive to sulphate reduction. However, the oxidation of iron is an important process on the surface of the SMS, where it first contacts water (Equation (5))

$$
\mathrm{Fe}^{2+}+\mathrm{O}_{2}+\mathrm{H}_{2} \mathrm{O} \rightarrow \mathrm{Fe}(\mathrm{OH})_{3(\mathrm{~s})}+2 \mathrm{H}^{+}
$$

In addition to $\mathrm{Fe}(\mathrm{OH})_{3(\mathrm{~s})}$, goethite $(\alpha-\mathrm{FeOOH})$, ferrihydrate $\left(5 \mathrm{Fe}_{2} \mathrm{O}_{3} \cdot \mathrm{H}_{2} \mathrm{O}\right)$, hematite $\left(\alpha-\mathrm{Fe}_{2} \mathrm{O}_{3}\right)$ and crystalline Fe can be formed. This results in an iron mass in crystalline or amorphous form that accumulates on the surface of the SMS.

The overall objective of this work was to evaluate the potential use of SMS for bioremediation of heavy metals from industrial waste water (Figure 1a). In the current study, experiments were designed to analyse the effectiveness and longevity of the biosorption process that is used in bioreactors that operate continuously for more than fourteen weeks, uses directly the SMS that is provided after the plastic sacks are separated, involves no agitation and uses different configurations and loads of contaminants, to develop a low-cost industrial-scale system [46].

\section{Materials and Methods}

\subsection{Raw Materials}

The SMS of Agaricus bisporus that was used in the present study was supplied by a mushroom producer in Pradejón (La Rioja, Spain). The biomass was supplied in waterproof plastic sacks. Therefore, it was necessary to separate the plastic bags and the SMS. The main characteristics of the SMS residues that were used in the experiments appear in Table 2.

Table 2. Physicochemical properties of raw SMS.

\begin{tabular}{lc}
\multicolumn{1}{c}{ Parameter } & Value \\
\hline Dry matter (\%) & 67.4 \\
Moisture (\% dry weight) & 52.6 \\
pH (1:5 water extract) & 7.2 \\
pH (saturation extract) & 7.9 \\
EC (1:10 water extract) $\left(\mathrm{dS} / \mathrm{m}^{\prime}\left(25^{\circ} \mathrm{C}\right)\right)$ & 6.2 \\
EC saturation extract $\left(\mathrm{dS} / \mathrm{m}\left(25^{\circ} \mathrm{C}\right)\right)$ & 22.1 \\
Total Organic C $(\%$ dry weight) & 54.3 \\
Oxidizable Organic C $(\%$ dry weight) & 24.9 \\
Total N (\% dry weight) & 2.16 \\
P (\% dry weight) & 0.69 \\
K (\% dry weight) & 2.2 \\
Ca (\% dry weight) & 10.8 \\
Mg (\% dry weight) & 0.83 \\
Na (\% dry weight) & 0.24 \\
Fe (ppm) & 1820 \\
Cu (ppm) & 50.7 \\
Cr (ppm) & 18.7 \\
Pb (ppm) & $<30$ \\
Mn (ppm) & 241.2 \\
Zn (ppm) & 189.9 \\
Ni (ppm) & $<20$ \\
Cd (ppm) & $<20$ \\
Chloride (\% dry weight) & 0.8 \\
Gypsum (qualitative) & Yes \\
C/N ratio & 11.5 \\
\hline & \\
\hline & \\
\hline
\end{tabular}


Because of the impossibility of having "real" industrial water that contains all metals that are studied in this work (lead, chromium, iron (II and III), cobalt, nickel, manganese, zinc, copper and aluminium), a synthetic effluent or solution with a known metal loading was prepared in the laboratory for the experiments. All reagents that were used were of analytical grade (GR for analysis, Merck, Germany).

To avoid precipitation due to the $\mathrm{pH}$ of the dissolution or chemical reaction between metals, the metals under study were used to create three different metal solutions (S1, S2 and S3) at different $\mathrm{pH}$ levels (12, 2.5 and 1.5 , respectively).

Law 5/2000 [47] establishes the instantaneous limit values for the pollutant load of the discharge to sewerage networks, collectors and sanitary installations. The maximum allowable discharge values of the Autonomous Community of La Rioja (CAR) were considered when determining the stock solutions' pollutant loading. Based on these data and to conduct the experiment with "very polluted water", the level of pollution of heavy metals used in this study was the result of multiplying the maximum allowable polluting load for each heavy metal by 25. Iron was an exception because of its importance. Thus, the iron level of pollution was the result of multiplying the maximum allowable polluting load by 50 . The goal was to prepare synthetic water with initial amounts of pollutant loadings that exceed the legal values established in the legislation and verify the effectiveness of the SMS.

Table 3 shows the concentrations of each metal, the corresponding allowable discharge limits in the CAR and the composition of the three solutions (S1, S2 and S3).

Table 3. Metal concentrations of raw dissolutions (mg/L).

\begin{tabular}{lccc}
\hline \multicolumn{1}{c}{ Metal } & $\begin{array}{c}\text { Legal Discharge Limit } \\
\text { in CAR (mg/L) }\end{array}$ & $\begin{array}{c}\text { Implemented } \\
\text { Concentration }(\mathbf{m g} / \mathbf{L})\end{array}$ & Dissolution Group \\
\hline Lead & 1 & 25 & S1, pH $>12$ \\
Chromium (total) & 0.5 & 10 & \\
\hline Iron (III) & 10 & 500 & $\mathrm{~S} 2, \mathrm{pH}<2.5$ \\
Cobalt & 1 & 25 & \\
Nickel & 5 & 100 & \\
Manganese & 2 & 50 & $\mathrm{~S} 3, \mathrm{pH}<1.5$ \\
\hline Iron (II) & 10 & 500 & \\
Zinc & 5 & 100 & \\
Copper & 2 & 50 & \\
Aluminium & 20 & 500 & \\
\hline
\end{tabular}

\subsection{Bioreactors}

Laboratory scale bioreactors were built for the experiments (Figure 1b). Six cylindrical methacrylate bioreactors with a total volume of $25 \mathrm{~L}$ and a working volume of $20 \mathrm{~L}$ were used. Each bioreactor was filled with $5 \mathrm{~kg}$ of SMS and $10 \mathrm{~L}$ of fluid. Two bioreactors were used for each kind of dissolution. The dimensions of the bioreactors ensured that the $5 \mathrm{~kg}$ of SMS were completely immersed in the fluid. This secured the anaerobic conditions that were necessary for the bioremediation process.

The design of the bioreactors (Figure $1 \mathrm{~b}$ ) follows the guidelines for down-flow reactors. This requires treatment cells with perforated bases (1) through which the effluent is drained to another chamber (2) before being discharged through the outlet (3). A layer of organic substrate (SMS) (4) is placed over this surface of the drain. A grid (5) is used to counteract any buoyancy of the organic substrate. The water flows vertically through the compost and is collected and discharged through a piping system. This design simulates traditional "wetlands" (aerobic and anaerobic lagoons systems). 


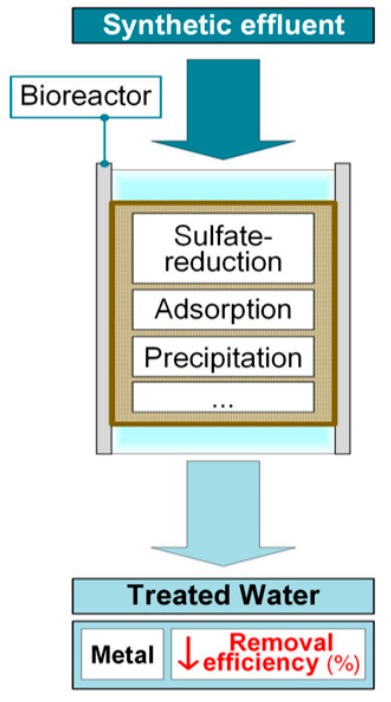

(a)

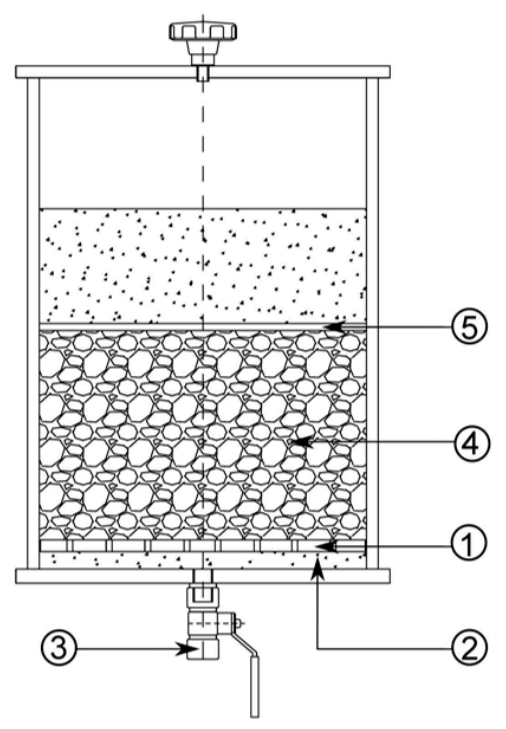

(b)

Figure 1. (a) Mechanisms for removal of heavy metals from synthetic effluent; (b) design of the bioreactors.

First, the bioreactors were inoculated with the synthetic effluent. Then, the inoculated bioreactors were incubated for 37 days at $25^{\circ} \mathrm{C}$ before adding the contaminated water continuously in a down-flow mode. Next, the bioreactors were fed the prepared contaminated water in a down-flow mode at two different feeding rates, namely $1 \mathrm{~L} /$ day and $100 \mathrm{~mL} /$ day. Thus, each type of synthetic effluent was treated with SMS under two different conditions. The hydraulic retention time (HRT) was limited to 10 days for the $1 \mathrm{~L} /$ day flow rate and 100 days for the $100 \mathrm{~mL} /$ day flow rate during the entire operation. The temperature of the bioreactors was maintained at $25^{\circ} \mathrm{C}$.

\subsection{Data Analysis}

Metal concentrations were quantified by an atomic absorption spectrophotometer on a regular basis (AAnalyst 800, Perkin Elmer, Norwalk, USA). The metal uptake $q(\mathrm{mg} / \mathrm{g}$ ) and the removal efficiency $\mathrm{E}(\%)$ of the biosorbent were calculated by Equations (6) and (7).

$$
\begin{gathered}
q=\frac{\left(\mathrm{C}_{0}-\mathrm{C}_{\mathrm{t}}\right) \mathrm{V}}{\mathrm{w}} \\
\mathrm{E}(\%)=\frac{\left(\mathrm{C}_{0}-\mathrm{C}_{\mathrm{t}}\right)}{\mathrm{C}_{0}} \cdot 100
\end{gathered}
$$

where $C_{0}$ and $C_{t}(\mathrm{mg} / \mathrm{L})$ are the initial and final metal concentrations of the solution, $V(\mathrm{~L})$ is the volume of the solution and $\mathrm{w}(\mathrm{g})$ is the amount of dry sorbent used.

All experiments were conducted in triplicate during the study. Thus, the mean of the results and a $95 \%$ confidence interval for the mean are shown in the following section.

\section{Results and Discussion}

\subsection{Effect of $p H$}

The $\mathrm{pH}$ of a solution is one of the most important parameters that control the biosorption process because it affects the solution chemistry of the metals, the activity of the functional groups in the biomass and the competition of metallic ions [48]. Thus, it is necessary to determine the $\mathrm{pH}$.

With alkaline influent waters (dissolution group S1, Figure 2, the $\mathrm{pH}$ of the outflow was reduced to circumneutral levels (6.4-7.2) when there was enough contact time between the contaminated water 
and the SMS. The decrease in the $\mathrm{pH}$ is due to: high partial pressures of carbon dioxide $\left(\mathrm{pCO}_{2}\right)$ arising from microbial respiration that depresses the $\mathrm{pH}$ and can accelerate the rate of calcium carbonate precipitation-a process that consumes alkalinity-[49] and cation exchange and the production of organic acids [50]. For a feeding rate of $100 \mathrm{~mL} /$ day, the $\mathrm{pH}$ was maintained at a value near circumneutral although the experiment concluded when a stationary regime was reached. However, when the feeding rate was $1 \mathrm{~L} /$ day, the $\mathrm{pH}$ rose from the neutral values that were achieved after the 37-day incubation period to the $\mathrm{pH}$ of the inflow once the stationary regime had been reached.

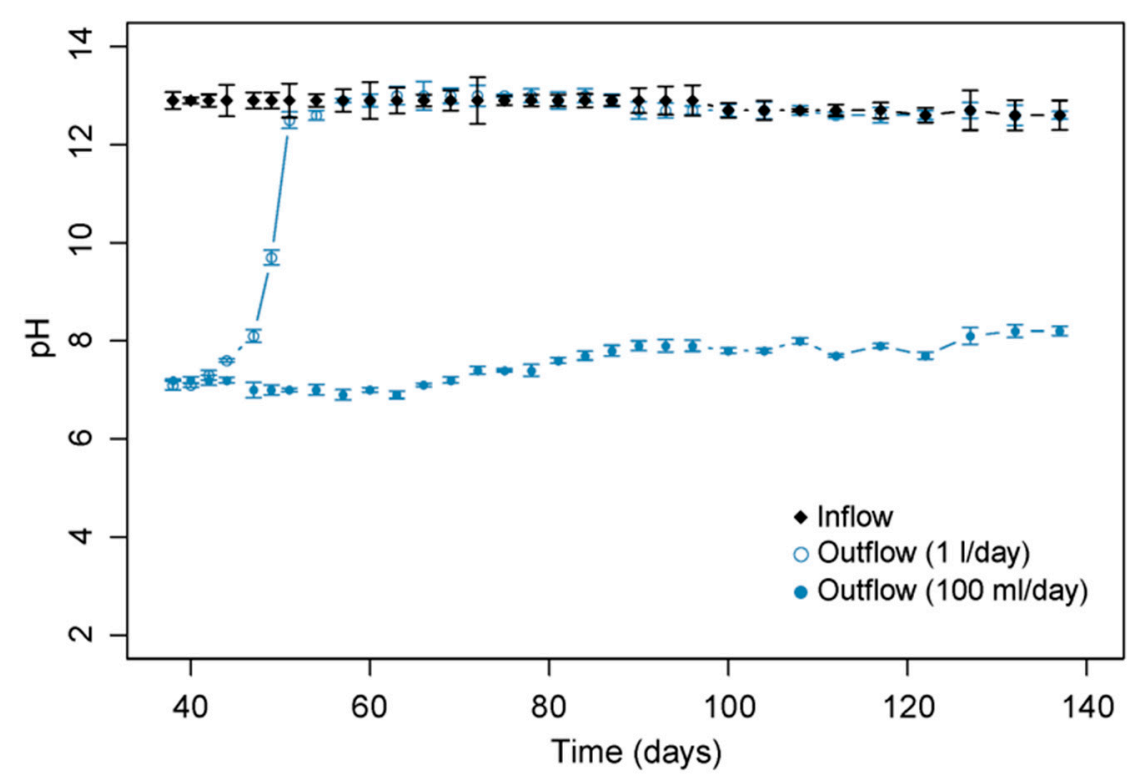

Figure 2. $\mathrm{pH}$ variations in reactors that were inoculated with alkaline influent waters-dissolution group S1-and were operated continuously for 14 weeks after 37 days of batch operation.

In the case of acid influent waters (dissolution groups S2 and S3, Figure 3a,b respectively), the $\mathrm{pH}$ of the outflow was raised. Different mechanisms are known to be responsible for the $\mathrm{pH}$ increment in acidic waters. They are: the natural alkalinity of the compost, the alkalinity that is generated by sulphate reduction and the alkalinity that is caused by carbonate dissolution [51]. Since the SMS that was used in the experiments contained limestone, the alkalinity generated by sulphate-reducing bacteria could not be estimated.

When the $\mathrm{pH}$ of the influent was approximately 2.5 (dissolution group S2, Figure 3a), the outflow was circumneutral consistently for both feeding rates. However, with lower $\mathrm{pH}$ values of the influent, such as a pH of 1.5-1.6 in the dissolution group S3 (Figure 3b), the increase in pH around circumneutral could be maintained only for a feeding rate of $100 \mathrm{~mL} /$ day. With a feeding rate of $1 \mathrm{~L} /$ day, the $\mathrm{pH}$ of the outflow ranged from 5.6 to 6.8 during the first two weeks of continuous feeding of the bioreactors with contaminated water. The $\mathrm{pH}$ of the outflow declined subsequently to the $2.2-2.6$ range, with a minimum value of 1.9 observed in the fourth week. These results seemed to indicate that ecosystems of sulphate-reducing bacteria growing in SMS remain active when contaminated water that has a $\mathrm{pH}$ as low as 1.5 is introduced to the system. However, under these circumstances, the flow rate must be reduced to a rate below $1 \mathrm{~L} /$ day or the HRT must be increased beyond 10 days to permit long-term activity of the sulphate-reducing ecosystem. More work is necessary to determine the optimum flow rate and residence time when the influent has a $\mathrm{pH}$ as low as 1.5. 


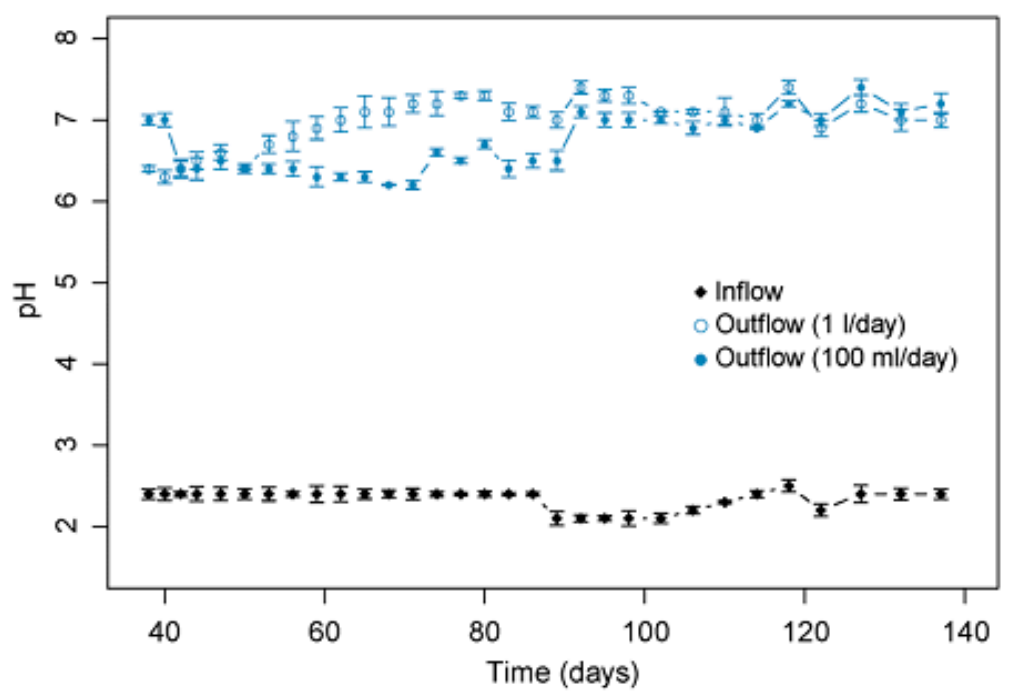

(a)

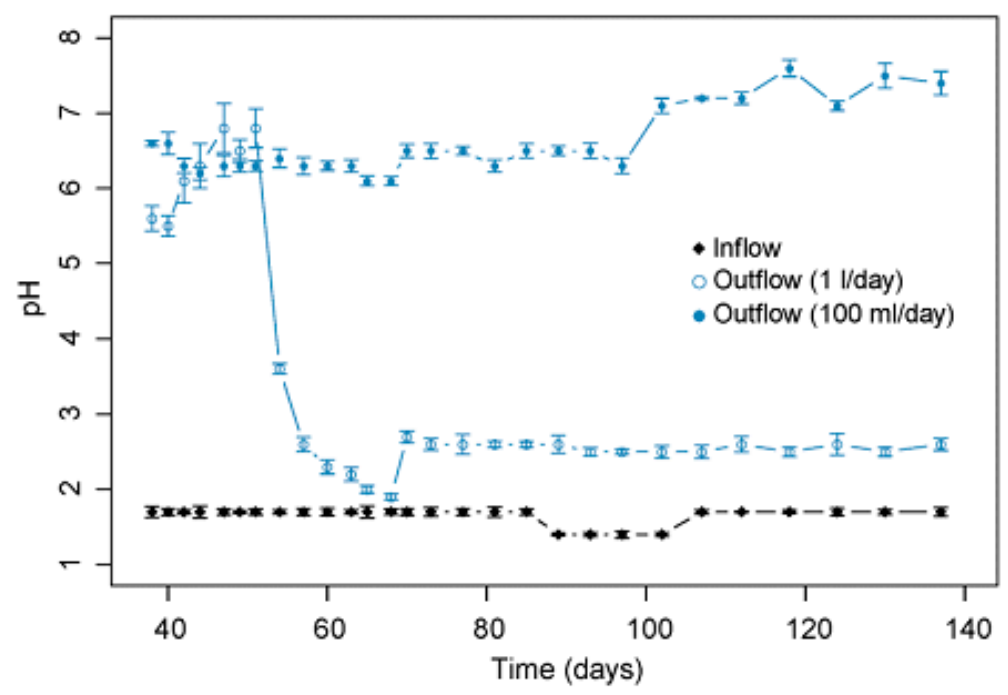

(b)

Figure 3. $\mathrm{pH}$ variations in reactors that were inoculated with acid influent waters-dissolution groups S2 (a) and S3 (b) - and were operated continuously for 14 weeks after 37 days of batch operation.

\subsection{Metal Removal}

\subsubsection{Lead}

Different lead removal efficiencies were observed at different feeding rates (Figure 4). Although a feeding rate of $100 \mathrm{~mL} /$ day had a removal efficiency of approximately $70 \%$ to $80 \%$ during the entire experiment, the removal efficiency with a feeding rate of $1 \mathrm{~L} /$ day was less than $50 \%$ initially, but, began to rise during the fourth week of treatment and achieved a level of about $87 \%$ in the seventh week. It maintained this to the end of the experiment. Despite the initial differences, SMS was able to remove lead in both alkaline and circumneutral conditions. The highest removal efficiencies were achieved at a feeding rate of $1 \mathrm{~L} /$ day, which is the most interesting option from an industrial point of view. In this case, the removal mechanisms of this metal could include precipitation because of the alkaline conditions ( $\mathrm{pH}$ around 13).

After seven weeks, the biosorption process under these conditions $(1 \mathrm{~L} /$ day) had stabilized and the removal efficiency remained constant to the end of the experiment. The results that appear in 
Figure 4 suggest that the potential of the SMS had not been exhausted, although there is no evidence to support this.

\subsubsection{Chromium}

A behaviour that was similar to that of lead was observed in chromium removal (Figure 4). Overall, about $80-84 \%$ of the influent chromium was removed throughout the experiment when the feeding rate was $100 \mathrm{~mL} /$ day. With a feeding rate of $1 \mathrm{~L} /$ day, the chromium removal efficiency increased from the $70-80 \%$ observed in the first five weeks of the biosorption process to an average of $89 \%$ during the remaining nine weeks of the experiment. In this case, the highest removal efficiencies were also obtained with a feeding rate of $1 \mathrm{~L} /$ day in alkaline conditions. This suggests that chromium sequestration also included precipitation. In addition, the chromium removal stabilized after the initial weeks. Again, the results suggested that the potential of the SMS had not been exhausted.

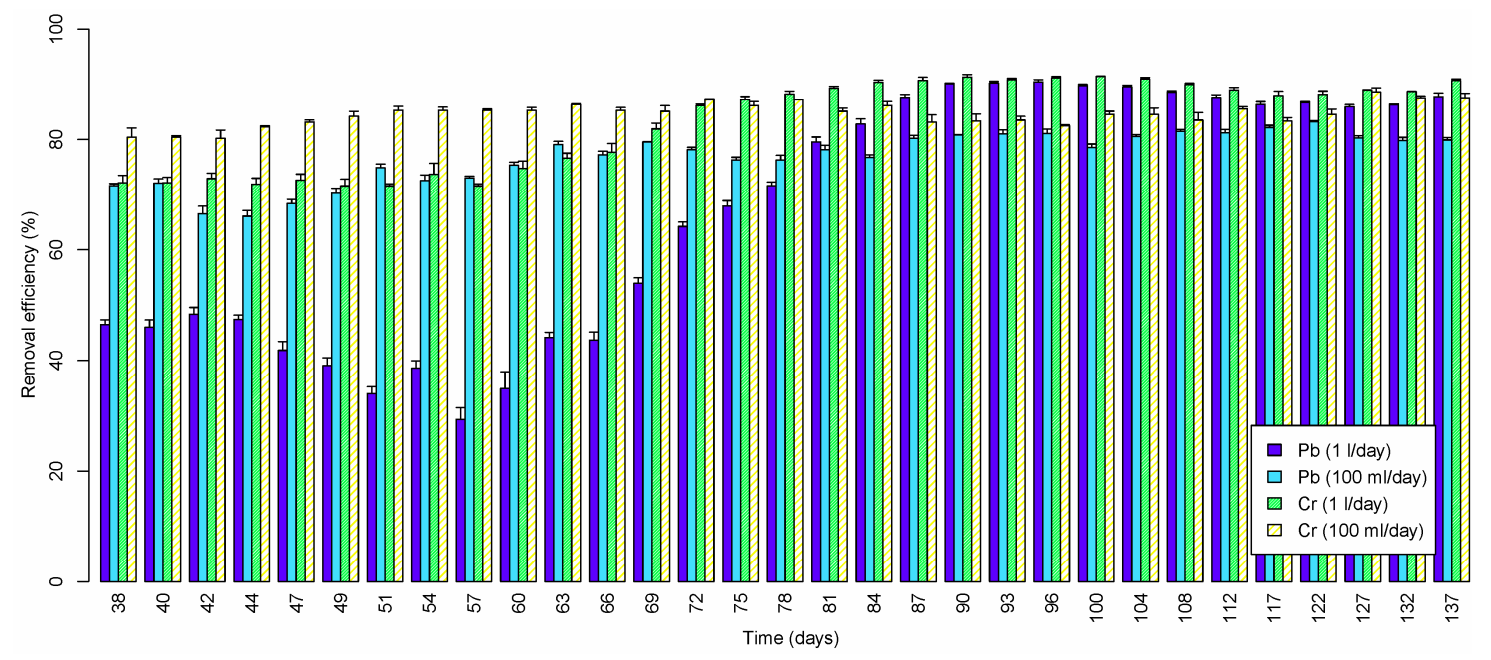

Figure 4. $\mathrm{Pb}$ and $\mathrm{Cr}$ removal efficiency (\%) using spent Agaricus bisporus as a function of reactor operation time.

\subsubsection{Nickel, Cobalt and Iron (III)}

In the bioreactors with solution S2 (feeding rates of $100 \mathrm{~mL} /$ day and $1 \mathrm{~L} /$ day), about 95-99\% of nickel, cobalt and the iron (III) loads were consistently removed while passing through the SMS (Figures 5 and 6). In fact, the outflow concentrations of these metals declined below the level of discharge concentration that the CAR allows in less than 15 days. The highest removal efficiencies were also obtained at a feeding rate of $1 \mathrm{~L} /$ day. The maximum removal capacity was achieved with a pH higher than 7.

The clearance rate was maintained during the entire experiment. The results suggest that the removal of these metals would continue for a period of time since the potential of the SMS had not been exhausted. More work is necessary to determine the longevity of the SMS with each of these metals. 


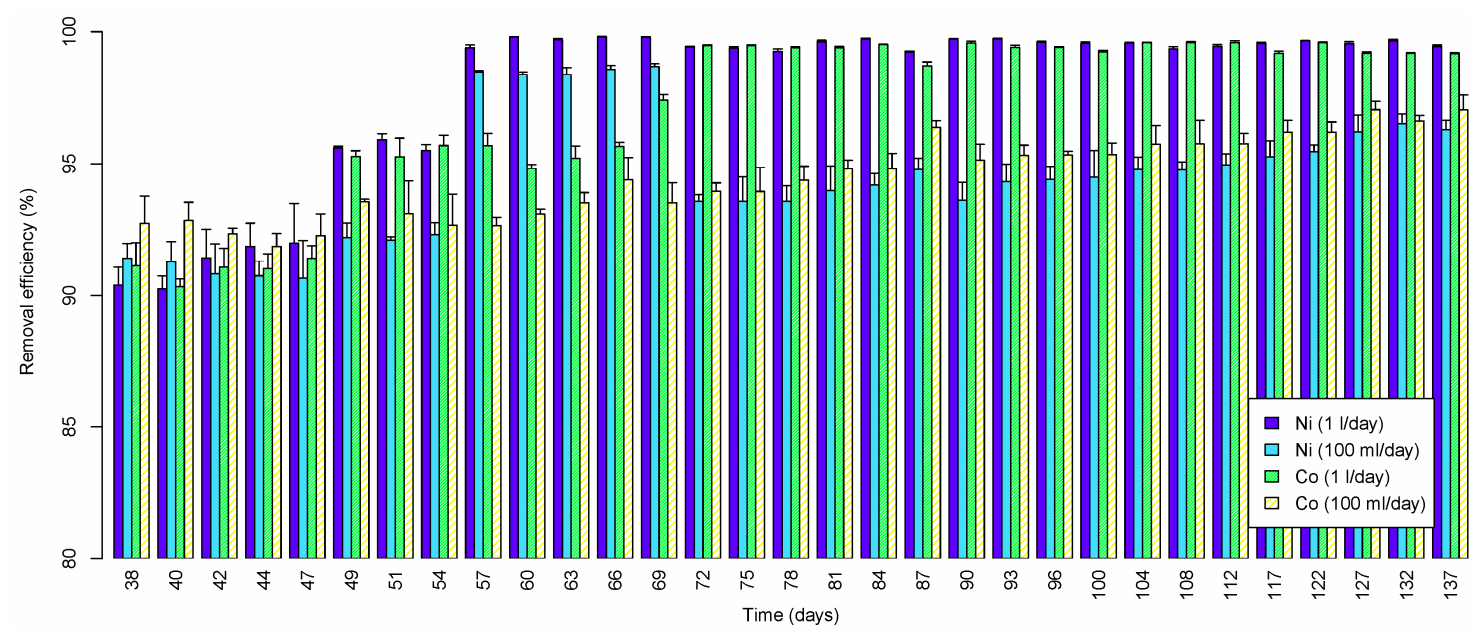

Figure 5. Ni and Co removal efficiency (\%) using spent Agaricus bisporus as a function of reactor operation time.

\subsubsection{Manganese}

In the case of manganese removal with SMS (Figure 6), the CAR standard discharge values were not attained. The manganese removal efficiency ranged from 80 to $90 \%$ when a feeding rate of $100 \mathrm{~mL} /$ day was used. However, with a feeding rate of $1 \mathrm{~L} /$ day, the manganese removal efficiency was $81 \%$ initially but rose during the first three weeks of the biosorption process and achieved its maximum value (about 99\%) for the following two weeks. Then, the manganese removal efficiency declined to levels of approximately $85 \%$. The competitive sorption characteristics of the metals mixture in the dissolution group S2 could explain these results: SMS exhibits the lowest selectivity toward manganese.

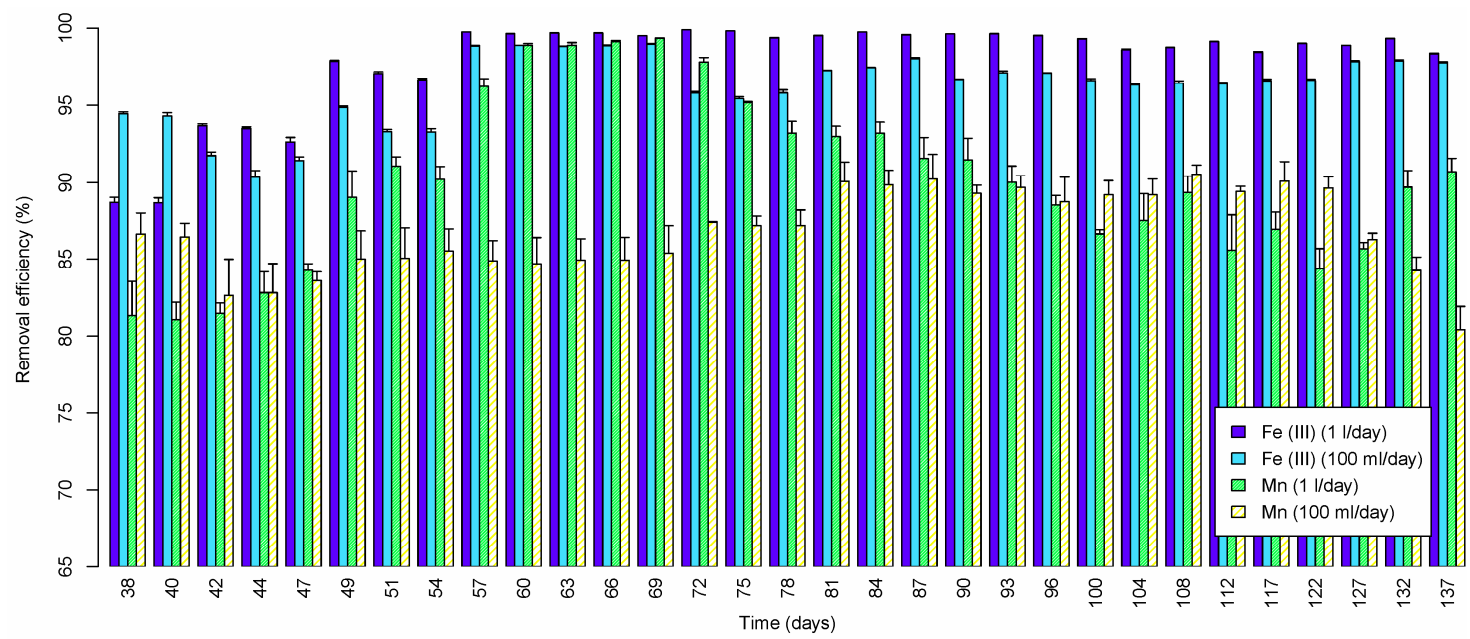

Figure 6. Fe (III) and Mn removal efficiency (\%) using spent Agaricus bisporus as a function of reactor operation time.

\subsubsection{Iron (II)}

The efficiency of the removal of iron (II) in the dissolution group S3 (Figure 7) was maintained consistently during the experiment with a feeding rate of $100 \mathrm{~mL} /$ day: SMS averaged about $94 \%$ removal of influent iron (II). The highest removal efficiencies were achieved at $\mathrm{pH}$ values that exceed 7. However, in the case of a flow rate of $1 \mathrm{~L} /$ day, after two weeks of high effectiveness, the removal efficiency declined continuously during the remainder of the experiment. This phenomenon occurs during the same time as the observed reduction of the outflow $\mathrm{pH}$. This illustrates the high correlation between $\mathrm{pH}$ and optimum iron (II) removal efficiency. 
These results suggest that SMS can remove heavy metals with a $\mathrm{pH}$ that is as low as 1.5. However, it is necessary to increase the contact time between SMS and low-pH waters in order to maintain the $\mathrm{pH}$ above 7 and the high removal efficiencies over time.

\subsubsection{Zinc}

A behaviour similar to that of iron (II) was observed with zinc removal at a feeding rate of $100 \mathrm{~mL} /$ day (Figure 7). In this case, about $96 \%$ of the influent zinc was removed. Again, the highest removal efficiencies were obtained at $\mathrm{pH}$ values that exceeded 7 . At a feeding rate of $1 \mathrm{~L} /$ day, the zinc removal efficiency declined continuously after two weeks of high effectiveness. As shown in Figure 7, the zinc removal dropped drastically and reached negative values, which indicates that previously precipitated metal had dissolved and returned to the solution. The results of this experiment suggest that the lower removal efficiencies may be due to the increased solubility of metal sulphides. As mentioned previously, more work is necessary to determine the optimum flow rate and residence time when the influent has a $\mathrm{pH}$ as low as 1.5.

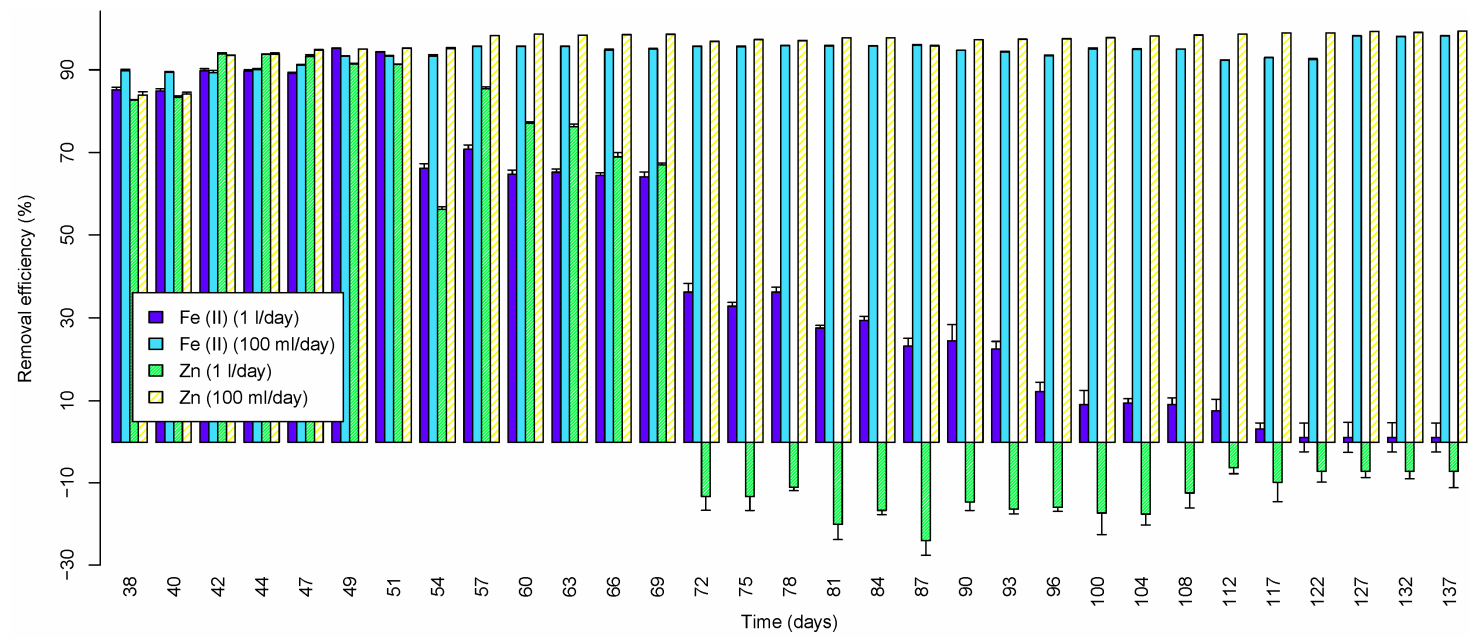

Figure 7. Fe (II) and Zn removal efficiency (\%) using spent Agaricus bisporus as a function of reactor operation time.

\subsubsection{Copper and Aluminium}

SMS provided an averaged approximately $96 \%$ removal of influent copper and $98 \%$ removal of influent aluminium at a feeding rate of $100 \mathrm{~mL} /$ day (Figure 8). In both cases, the highest removal efficiencies (around 99\%) were obtained at $\mathrm{pH}$ values that exceeded 7. However, as in the case of iron (II), the removal efficiency declined continuously throughout the remainder of the experiment following two weeks of high effectiveness at a flow rate of $1 \mathrm{~L} /$ day. An average of $51-55 \%$ of removal efficiency was maintained for aluminium and copper at a $\mathrm{pH}$ of 2.5 .

Figure 9 summarizes the removal efficiencies that were reached in this study. Figure 9 a shows that, in the bioreactors with solution S1, about $87 \%$ of lead and $89 \%$ of chromium loads were removed respectively during the biosorption process. In the bioreactors with solution S2 (Figure $9 \mathrm{~b}$ ), about $97 \%$ of nickel, $97 \%$ of cobalt and $97 \%$ of iron (III) loads were removed while passing through the SMS. For the manganese case, a removal efficiency of $99 \%$ was achieved during the biosorption process. Figure $9 \mathrm{c}$ shows the iron (II), zinc, aluminium and copper removal efficiency in the dissolution group S3. About $94 \%$ of the iron (II) and $96 \%$ of the zinc were removed and an average removal efficiency of $53 \%$ was maintained for both, aluminium and copper. 


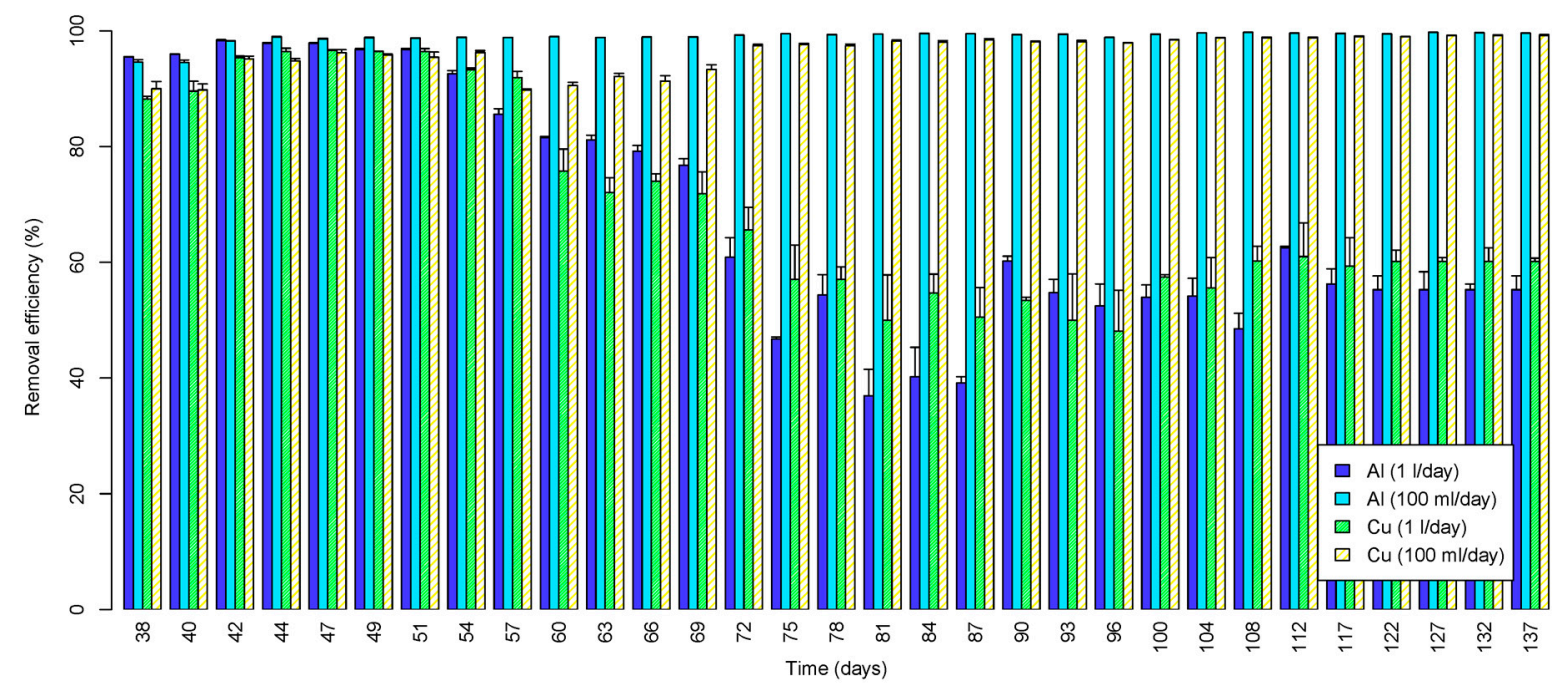

Figure 8. $\mathrm{Al}$ and $\mathrm{Cu}$ removal efficiency (\%) using spent Agaricus bisporus as a function of reactor operation time.

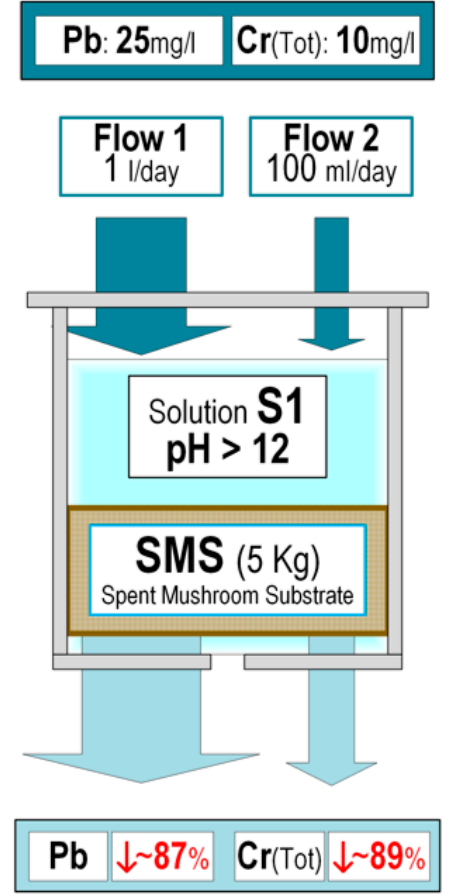

(a)
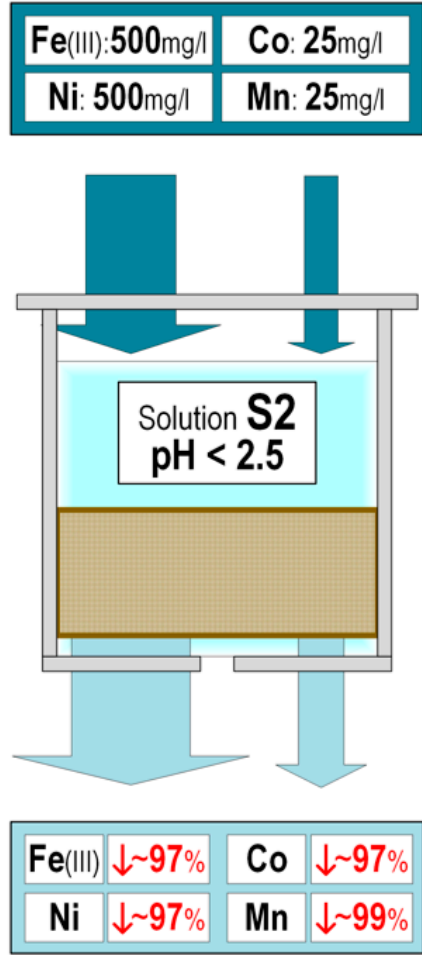

(b)
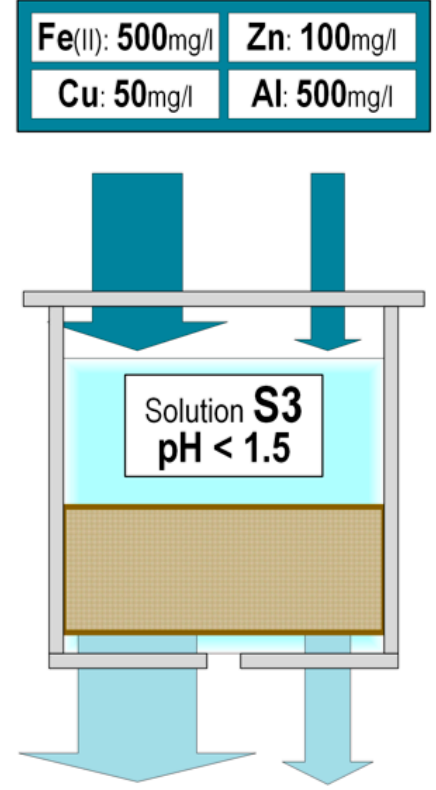

\begin{tabular}{|c|c|c|c|}
\hline $\mathbf{F e}($ II) & $\downarrow \sim 94 \%$ & $\mathbf{Z n}$ & $\downarrow \sim 96 \%$ \\
\hline $\mathbf{C u}$ & $\downarrow \sim 53 \%$ & $\mathrm{Al}$ & $\downarrow \sim 53 \%$ \\
\hline
\end{tabular}

(c)

Figure 9. Removal efficiency (\%) of the heavy metals that were analysed. Dissolution groups S1 (a), S2 (b) and S3 (c).

\section{Conclusions}

The present study has investigated the potential of SMS on the bioremediation of different heavy metals that have been dissolved in water at different $\mathrm{pH}$ values using SMS as a biosorbent. The work has shown that the removal of most analysed heavy metals is strongly affected by the $\mathrm{pH}$ of the medium. Lead and chromium were removed at high alkaline $\mathrm{pH}$ values (around 13), whereas the highest removal efficiencies for the other analysed heavy metals (Fe(III), Ni, Co, Fe(II), Zn, Al and Cu) were achieved at $\mathrm{pH}$ values of approximately 7 . 
SMS was found to be useful as a low-cost bioremediating agent for the removal of different heavy metals from polluted water. Its use provides an ecological alternative to the disposal of SMS. However, it must be noted that the effluent, which is substantially free of dissolved heavy metals, has a significant organic charge (high Biological Oxygen Demand-BOD—levels). Therefore, an oxidation process in series to reduce the BOD discharge levels to the limits permitted by standards should be considered.

Much work remains to be done. Field studies based on laboratory-scale experiments need to be conducted using spent mushroom substrate of Agaricus bisporus to remove heavy metals from water before commercially viable systems will become available. To facilitate the use of this technology at an industrial level, more work is necessary to determine: (1) the optimal system configuration and longevity of the SMS to reduce iron (III), nickel, cobalt and manganese at an influent $\mathrm{pH}$ of 2.5 ; (2) the optimal flow rate and residence time when the influent has a $\mathrm{pH}$ as low as 1.5; and (3) the possibility of improving the removal efficiency of lead and chromium when alkaline, contaminated water is introduced to the system.

However, with a global political shift towards sustainable and green bioremediation technologies, the use of spent mushroom substrate to remove heavy metals from water waste provides an efficient, economic and sustainable green remediation technology.

Author Contributions: Experimental works: F.A.-E., M.C.-B. and E.P.V.-G. Analysed the data: A.G.-M. Results analysis and manuscript preparation: all authors.

Funding: This research received no external funding.

Acknowledgments: The authors wish to thank the La Rioja Government as well as to the Institute of Riojan Studies (IER) for funding part of this research.

Conflicts of Interest: The authors declare no conflict of interest.

\section{References}

1. Ayangbenro, A.S.; Babalola, O.O. A New Strategy for Heavy Metal Polluted Environments: A Review of Microbial Biosorbents. Int. J. Environ. Res. Public Health 2017, 14, 94. [CrossRef] [PubMed]

2. Umrania, V.V. Bioremediation of toxic heavy metals using acidothermophilicautotrophes. Bioresour. Technol. 2006, 97, 1237-1242. [CrossRef] [PubMed]

3. Wang, J.; Chen, C. Biosorbents for heavy metals removal and their future. Biotechnol. Adv. 2009, 27, 195-226. [CrossRef] [PubMed]

4. Chen, M.; Qin, X.; Zeng, G.; Li, J. Impacts of human activity modes and climate on heavy metal "spread" in groundwater are biased. Chemosphere 2016, 152, 439-445. [CrossRef] [PubMed]

5. Vargas, M.C.; López, M.J.; Suárez, F.; Moreno, J. Compost as a source of microbial isolates for the bioremediation of heavy metals: In vitro selection. Sci. Total Environ. 2012, 431, 62-67. [CrossRef] [PubMed]

6. Volesky, B. Detoxification of metal-bearing effluents: Biosorption for the next century. Hidrometallurgy 2001, 59, 203-216. [CrossRef]

7. Wu, G.; Kang, H.; Zhang, X.; Shao, H.; Chu, L.; Ruan, C.A. A critical review on the bio-removal of hazardous heavy metals from contaminated soils: Issues, progress, eco-environmental concerns and opportunities. J. Hazard. Mater. 2010, 174, 1-8. [CrossRef] [PubMed]

8. Jiménez, M.; Medina, D. Use of surfactant-modified zeolites and clays for the removal of heavy metals from water. Water 2017, 9, 235. [CrossRef]

9. Srivastava, S.; Agrawal, S.B.; Mondal, M.K. A review on progress of heavy metal removal using adsorbents of microbial and plant origin. Environ. Sci. Pollut. Res. 2015, 22, 15386-15415. [CrossRef] [PubMed]

10. Dixit, R.; Malaviya, D.; Pandiyan, K.; Singh, U.B.; Sahu, A.; Shukla, R.; Paul, D. Bioremediation of heavy metals from soil and aquatic environment: An overview of principles and criteria of fundamental processes. Sustainability 2015, 7, 2189-2212. [CrossRef]

11. Kapoor, A.; Viraraghavan, T. Fungal biosorption—An alternative treatment option for heavy metal bearing wastewater: A review. Bioresour. Technol. 1995, 53, 195-206.

12. McGuinness, M.; Dowling, D. Plant-associated bacterial degradation of toxic organic compounds in soil. Int. J. Environ. Res. Public Health 2009, 6, 2226-2247. [CrossRef] [PubMed] 
13. Vijayaraghavan, K.; Jegan, J.; Palanivelu, K.; Velan, M. Removal and recovery of copper from aqueous solution by eggshell in a packed column. Miner. Eng. 2005, 18, 545-547. [CrossRef]

14. Roberts, D.A.; Shiels, L.; Tickle, J.; Nys, R.; Paul, N.A. Bioremediation of Aluminium from the Waste Water of a Conventional Water Treatment Plant Using the Freshwater Macroalga Oedogonium. Water 2018, 10, 626. [CrossRef]

15. Al-Qodah, Z. Biosorption of heavy metal ions from aqueous solutions by activated sludge. Desalination 2006, 196, 164-176. [CrossRef]

16. Chuah, T.G.; Jumasiah, A.; Azni, I.; Katayon, S.; Choong, S.Y.T. Rice husk as a potentially low-cost biosorbent for heavy metal and dye removal: An overview. Desalination 2005, 175, 305-316. [CrossRef]

17. Vijayaraghavan, K.; Yun, Y.-S. Bacterial biosorbents and biosorption. Biotechnol. Adv. 2008, 26, $266-291$. [CrossRef] [PubMed]

18. Al-Asheh, S.; Banat, F.; Al-Rousan, D. Beneficial reuse of chicken feathers in removal of heavy metals from wastewater. J. Clean. Prod. 2003, 11, 321-326. [CrossRef]

19. Foo, L.P.Y.; Tee, C.Z.; Raimy, N.R.; Hassell, D.G.; Lee, L.Y. Potential Malaysia agricultural waste materials for the biosorption of cadmium(II) from aqueous solution. Clean Technol. Environ. Policy 2012, 14, $273-280$. [CrossRef]

20. Jain, M.; Garg, V.; Kadirvelu, K.; Sillanpaä, M. Adsorption of heavy metals from multi-metal aqueous solution by sunflower plant biomass-based carbons. Int. J. Environ. Sci. Technol. 2016, 13, 493-500. [CrossRef]

21. Ribas, L.C.; De Mendonça, M.M.; Camelini, C.M.; Soares, C.H. Use of spent mushroom substrates from Agaricus subrufescens (syn. A. blazei, A. brasiliensis) and Lentinula edodes productions in the enrichment of a soil-based potting media for lettuce (Lactuca sativa) cultivation: Growth promotion and soil bioremediation. Bioresour. Technol. 2009, 100, 4750-4757. [PubMed]

22. Van Tam, N.; Wang, C.H. Use of spent mushroom substrate and manure compost for Honeydew melon seedlings. J. Plant Growth Regul. 2015, 34, 417-424. [CrossRef]

23. Gobierno de La Rioja (Consejería de Agricultura, Ganadería y Medio Ambiente). Champiñones y Setas, Cuaderno de Campo; Gobierno de la Rioja: La Rioja, España, 2001; Volume 48, pp. 7-13.

24. Semple, K.T.; Reid, B.J.; Fermor, T.R. Impact of composting strategies on the treatment of soils contamined with organic pollutants: A review. Environ. Pollut. 2001, 112, 269-283. [CrossRef]

25. Jordan, S.N.; Mullen, G.J.; Murphy, M.C. Composition variability of spent mushroom compost in Ireland. Bioresour. Technol. 2008, 99, 411-418. [CrossRef] [PubMed]

26. Dvorak, D.H.; Hedin, R.S.; Edenborn, H.M.; Mcintire, P.E. Treatment of metal-contaminated water using bacterial sulfate reduction: Results from pilot-scale reactors. Biotechnol. Bioeng. 1992, 40, 609-616. [CrossRef] [PubMed]

27. Hammack, R.W.; Hedin, R.S. Microbial sulphate reduction for the treatment of acid mine drainage: A laboratory study. In Proceedings of the Ninth Annual West Virginia Surface Mine Drainage Task Force Symposium, Morgantown, WV, USA, 25-26 April 1989; pp. 673-680.

28. Finney, K.N.; Ryu, C.; Sharifi, V.N.; Swithenbank, J. The reuse of spent mushroom compost and coal tailings for energy recovery: Comparison of thermal treatment technologies. Bioresour. Technol. 2009, 100, 310-315. [CrossRef] [PubMed]

29. Kwack, Y.; Song, J.H.; Shinohara, Y.; Maruo, T.; Chun, C. Comparison of six spent mushroom composts as growing media for transplant production of lettuce. Compost Sci. Util. 2012, 20, 92-96. [CrossRef]

30. Rao, J.R.; Watabe, M.; Stewart, T.A.; Millar, B.C.; Moore, J.E. Pelleted organo-mineral fertilisers from composted pig slurry solids, animal wastes and spent mushroom compost for amenity grasslands. Waste Manag. 2007, 27, 1117-1128. [CrossRef] [PubMed]

31. Gonani, Z.; Riahi, H.; Sharifi, K. Impact of using leached spent mushroom compost as a partial growing media for horticultural plants. J. Plant Nutr. 2012, 34, 337-344. [CrossRef]

32. Medina, E.; Paredes, C.; Pérez-Murcia, M.D.; Bustamante, M.A.; Moral, R. Spent mushroom substrates as component of growing media for germination and growth of horticultural plants. Bioresour. Technol. 2009, 100, 4227-4232. [CrossRef] [PubMed]

33. Zhang, C.K.; Gong, F.; Li, D.S. A Note on the Utilization of Spent Mushroom Composts in Animal Feeds. Bioresour. Technol. 1995, 52, 89-91. [CrossRef]

34. Lau, K.L.; Tsang, Y.Y.; Chiu, S.W. Use of spent mushroom compost to bioremediate PAH-contaminated samples. Chemosphere 2003, 52, 1539-1546. [CrossRef] 
35. Ahlawat, O.P.; Gupta, P.; Kumar, S.; Sharma, D.K.; Ahlawat, K. Bioremediation of Fungicides by Spent Mushroom Substrate and Its Associated Microflora. Indian J. Microbiol. 2010, 50, 390-395. [CrossRef] [PubMed]

36. Martín-Benito, J.M.; Rodríguez-Cruz, M.S.; Andrades, M.S.; Sánchez-Martín, M.J. Assessment of spent mushroom substrate as sorbent of fungicides: Influence of sorbent and sorbate properties. J. Environ. Qual. 2012, 41, 814-822. [CrossRef] [PubMed]

37. CórdovaJuárez, R.A.; Gordillo Dorry, L.L.; Bello-Mendoza, R.; Sánchez, E. Use of spent substrate after Pleurotus pulmonarius cultivation for the treatment of chlorothalonil containing wastewater. J. Environ. Manag. 2012, 92, 948-952. [CrossRef] [PubMed]

38. Chiu, S.W.; Gao, T.; Chan, C.S.S.; Ho, C.K.M. Removal of spilled petroleum in industrial soils by spent compost of mushroom Pleurotus pulmonarius. Chemosphere 2009, 75, 837-842. [CrossRef] [PubMed]

39. Chang, I.S.; Shin, P.K.; Kim, B.H. Biological treatment of acid mine drainage under sulphate-reducing conditions with solid waste materials as substrate. Water Res. 2000, 34, 1269-1277. [CrossRef]

40. Cheong, Y.W.; Das, B.K.; Roy, A.; Bhattacharya, J. Performance of a SAPS-Based Chemo-Bioreactor Treating Acid Mine Drainage Using Low-DOC Spent Mushroom Compost, and Limestone as Substrate. Mine Water Environ. 2010, 29, 217-224. [CrossRef]

41. Singh, R.; Ahlawat, O.P.; Rajor, A. Identification of the potential of microbial combinations obtained from spent mushroom cultivation substrates for use in textile effluent decolorization. Bioresour. Technol. 2012, 125, 217-225. [CrossRef] [PubMed]

42. Chen, G.Q.; Zeng, G.M.; Tu, X.; Huang, G.H.; Chen, Y.N. A novel biosorbent: Characterization of the spent mushroom compost and its application for removal of heavy metals. J. Environ. Sci. 2005, 17, 756-760.

43. Chen, G.Q.; Zeng, G.M.; Tu, X.; Niu, C.G.; Huang, G.H.; Jiang, W. Application of a by-product of Lentinusedodes to the bioremediation of chromate contaminated water. J. Hazard. Mater. 2006, 135, $249-255$. [CrossRef] [PubMed]

44. Dai, J.; Cen, F.; Ji, J.; Zhang, W.; Xu, H. Biosorption of lead(II) in aqueous solution by spent mushroom tricholoma lobayense. Water Environ. Res. 2012, 84, 291-298. [CrossRef] [PubMed]

45. Xu, H.; Chen, Y.; Huang, H.; Liu, Y.; Yang, Z. Removal of lead (II) and cadmium (II) from aqueous solutions using spent Agaricus bisporus. Can. J. Chem. Eng. 2012, 91, 421-431. [CrossRef]

46. Alba, F.; Ordieres, J.; Vergara, E.; Martínez-de-Pisón, F.J.; Pernía, A.V.; Martínez-de-Pisón, E.; Castejón, M.; González, A. Procedimiento y Sistema Para el Tratamiento de Aguas Contaminadas con Metales Pesados. ES Patent No. 2325349, 31 July 2007.

47. Law 5/2000, of 25 October, on Sanitation and Treatment of Waste Water from La Rioja; Nr 273; Official State Bulletin of Government of Spain: La Rioja, Spain, 2000; pp. 39588-39603.

48. Galun, M.; Galun, E.; Siegel, B.Z.; Keller, P.; Lehr, H.; Siegel, S.M. Removal of metal ions from aqueous solutions by Pencillium biomass: Kinetic and uptake parameters. Water Air Soil Pollut. 1978, 33, 359-371. [CrossRef]

49. Mayes, W.M.; Batty, L.C.; Younger, P.L.; Jarvis, A.P.; Kõiv, M.; Vohla, C.; Mander, U. Wetland treatment at extremes of pH: A review. Sci. Total Environ. 2009, 407, 3944-3957. [CrossRef] [PubMed]

50. Ross, S.M. Overview of the hydrochemistry and solute processes in British wetlands. In Hydrology and Hydrochemistry of British Wetlands; John Wiley: Chichester, UK, 1995.

51. Hammack, R.W.; Edenborn, H.M. The removal of nickel from mine waters using bacterial sulfate reduction. Appl. Microbiol. Biotechnol. 1992, 37, 674-678. [CrossRef]

(C) 2019 by the authors. Licensee MDPI, Basel, Switzerland. This article is an open access article distributed under the terms and conditions of the Creative Commons Attribution (CC BY) license (http://creativecommons.org/licenses/by/4.0/). 